Research Article

\title{
The Influence of a Thermal Treatment on the Decay Resistance of Wood via FTIR Analysis
}

\author{
Yinan Hao, ${ }^{1}$ Yanfei Pan, ${ }^{1}$ Rui Du, ${ }^{1}$ Yamei Wang, ${ }^{1}$ Zhangjing Chen, ${ }^{2}$ Xiaotao Zhang, ${ }^{1}$ and \\ Ximing Wang $\mathbb{1}^{1}$ \\ ${ }^{1}$ College of Material Science and Art Design, Inner Mongolia Agricultural University, Hohhot 010018, China \\ ${ }^{2}$ Department of Sustainable Biomaterials, Virginia Tech, Blacksburg, VA 24061, USA \\ Correspondence should be addressed to Ximing Wang; wangximing@imau.edu.cn
}

Received 19 August 2017; Revised 7 November 2017; Accepted 4 December 2017; Published 28 January 2018

Academic Editor: Vincenzo Guarino

Copyright (c) 2018 Yinan Hao et al. This is an open access article distributed under the Creative Commons Attribution License, which permits unrestricted use, distribution, and reproduction in any medium, provided the original work is properly cited.

The decay resistance of wood can be improved via a vacuum heat treatment. The amount of nutrients from cellulose, hemicellulose, and lignin and amount of sugars needed by the fungi during their growth were investigated. The results showed that the absorbance peaks corresponding to absorbed $\mathrm{CH}_{3}-\mathrm{CH}_{2^{-}}, \mathrm{C}=\mathrm{O}$, and the benzene ring skeleton stretching vibration all noticeably weakened with increased heat treatment. This indicated that the cellulose, hemicellulose, and lignin degraded to varying degrees. The specimens with a higher initial moisture content (MC) showed greater amounts of nutrient degradation after $2 \mathrm{~h}$ at the same heat treatment temperature. The chemical analysis results were in good agreement with the Fourier transform infrared (FTIR) analysis results. The decay resistance tests showed that the average mass loss of the heat-treated specimens was up to $10.8 \%$, in contrast to $22.23 \%$ for the untreated specimens. Furthermore, the FTIR analysis of the heat and decay-resistance test showed that the vibration wave peaks that corresponded to $\mathrm{CH}_{3}-\mathrm{CH}_{2}$ - at $2954 \mathrm{~cm}^{-1}$ showed noticeably less separation at higher heating temperature. This demonstrated that the cellulose hydrolysis in the wood decreased at higher heating temperatures, which explained why the decay resistance increased with increased heat treatment.

\section{Introduction}

Wood is a sustainable, nontoxic, and recyclable natural material having high strength and an aesthetic appearance. Because of these superior characteristics, wood is popular and widely used in many areas. However, under suitable climatic conditions, wood is easily biodegradable and vulnerable to various organisms like fungi and insects $[1,2]$. Wood contains cellulose, hemicellulose, lignin, and small amounts of sugars. It comprises $40 \%$ to $50 \%$ cellulose, $15 \%$ to $25 \%$ hemicellulose, and $20 \%$ to $40 \%$ lignin [3]. The cell walls of wood are mostly filled with these organic polymers. Ninety percent of these organic polymers can be broken down by the enzymes of wood decay fungi and then utilized by these fungi. Therefore, the cell walls are the primary source of nutrients for wood decay fungi $[4,5]$. The fungi degrade the cell walls through various ways [6-8]. The degradation compromises the structural integrity of the cell walls, negatively affects the mechanical properties of the wood, reduces the life span of the wood in service, and may even cause the wood to fall apart at severe stages of decay.

Thermal treatment is a wood improvement and preservation process against biotic and abiotic factors $[9,10]$. Heat treatment consists of a wood pyrolysis torrefaction performed in a very poor oxygen atmosphere to avoid wood combustion. When wood is treated via heat, the degradation of cellulose, hemicellulose, and lignin will take place at varying degrees. Condensation, formation of new linkages, and esterification reactions will also occur [11, 12]. As a result, these changes will reduce the amount of nutrients needed by the wood decay fungi. They will also alter their living environment, consequently inhibiting fungal growth and hence improving the decay resistance of the wood. Nunes et al. [13] studied the resistance of wood heat treated by hot oil bath (HOB) to the termite Reticulitermes grassei and concluded that, despite the slightly higher mortality of 
termites in treated samples and smaller mass loss, the difference was not significant. However, when treated and untreated counterpart wood samples were side by side during exposure, termites preferred untreated wood. These last results [13] could be justified by the addition of oil into the wood during the thermal modification process. However, in such a treatment, the oil is sufficient to make the wood treated with it more hydrophobic, making it more resistant to the attack of fungi and termite. However, there is little research focusing on the decay resistance of fastgrowing northwest wood via vacuum heat treatment. It is important for northwest wood to store water, prevent soil erosion, and prevent dust storms in the northwestern district of China. There have been limited studies on the changes in the amounts of the nutrients in heat-treated wood and in the decay resistance of heat-treated wood. The amount of nutrients from the cellulose, hemicellulose, and lignin of wood needed for the wood decay fungi was investigated. The amounts of the $\mathrm{OH}$ hydrophilic group decreased via vacuum heat treatment. The nutrients needed by the decay fungi were decreased via vacuum heat treatment owing to cellulose, hemicellulose, and lignin pyrolysis [14].

This paper reports a Fourier transform infrared (FTIR) spectroscopy analysis on the changes in the nutrients of heat-treated specimens to analyze the mechanism between the decay resistance and wood chemical components, and we hope that this study will add new helpful information to this area of research about fast-growing northwest wood.

\section{Experimental}

2.1. Materials. Poplar trees (Populus beijingensis), with an average diameter at breast height $(\mathrm{DBH})$ of $39 \mathrm{~cm}$ grown in the Hohhot region of Inner Mongolia, were harvested to provide the experimental materials. Twelve sets of specimens via $20 \mathrm{~mm} \times 20 \mathrm{~mm} \times 20 \mathrm{~mm}$ size (radial $\times$ tangential $\times$ longitudinal) were prepared. Each set contained 20 specimens.

2.2. Heat Treatment. The specimens were placed into a boxtype resistance furnace (FSX2-12-15N, Tianjin, China) by aeration of nitrogen $\left(\mathrm{N}_{2}\right)$ as the heating medium at a flow rate of $20 \mathrm{~mL} / \mathrm{min}$. The initial nominal MC of the specimens was $30 \%, 15 \%$, and $5 \%$, respectively. The heating temperatures were $180^{\circ} \mathrm{C}, 200^{\circ} \mathrm{C}$, and $220^{\circ} \mathrm{C}$. The heating lasted $2 \mathrm{~h}$ for all of the heating treatments. The set number of specimens, their initial nominal MC, and heating temperatures are summarized in Table 1.

After the heat treatment, one-third of the specimens were used in the FTIR analysis, and the rest were used in the decay resistance tests. The untreated specimens (Table 1) were also used in the FTIR analysis.

\subsection{Methods}

2.3.1. FTIR Analysis. An FTIR device (Ten-Sor 27, Bruker, Karlsruhe, Germany), with a resolution of $4 \mathrm{~cm}^{-1}$ and spectra wave number range of $400 \mathrm{~cm}^{-1}$ to $4000 \mathrm{~cm}^{-1}$, was
TABLE 1: The specimen conditions and heating parameters of the experiment.

\begin{tabular}{lccc}
\hline $\begin{array}{l}\text { Set no. of } \\
\text { specimens }\end{array}$ & $\begin{array}{c}\text { Moisture content, } z \\
(\%)\end{array}$ & $\begin{array}{c}\text { Temperature } \\
\left({ }^{\circ} \mathrm{C}\right)\end{array}$ & $\begin{array}{c}\text { Time } \\
(\mathrm{h})\end{array}$ \\
\hline 1 & 30 & 220 & 2 \\
2 & 15 & 220 & 2 \\
3 & 5 & 220 & 2 \\
4 & 30 & 200 & 2 \\
5 & 15 & 200 & 2 \\
6 & 5 & 200 & 2 \\
7 & 30 & 180 & 2 \\
8 & 15 & 180 & 2 \\
9 & 5 & 180 & 2 \\
10 & 30 & Untreated & - \\
11 & 15 & Untreated & - \\
12 & 5 & Untreated & - \\
\hline
\end{tabular}

used to collect and analyze the spectrum data. Specimens that required FTIR analysis were broken into small pieces, mixed with $\mathrm{KBr}$ at $1: 25$ weight ratio, milled into even mixtures, and then compressed into discs under $9 \mathrm{~kg} / \mathrm{cm}^{2}$ pressure for $1 \mathrm{~min}$.

2.3.2. Decay Resistance Tests. The decay resistance tests followed the Chinese National Standard for Wood Durability Test GB/T 139421 [15]. The white rot fungus (Coriolus versicolor) was obtained from the Chinese Collection and Management Centre for Forest Microorganisms and was used in the decay resistance tests. The wood specimens were put in contact with the white rot for 4 weeks. The differences in the nutrients before and after the decay resistance tests of the untreated and heat-treated specimens were investigated via FTIR analysis.

2.3.3. Chemical Analysis of the Contents of Nutrients. Determination of the contents of the nutrients followed the Chinese National Standard GB/T 2677.10 [16] for holocellulose, GB/T 744 [17] for cellulose, and GB/T 2677.8 [18] for lignin. For each experimental condition, three specimens were used in determining each nutrient, and the average was calculated within an allowable error.

\section{Results and Discussion}

3.1. FTIR Analysis of Heat-Treated Specimens. Figures 1 and 2 show the FTIR spectra from $4000 \mathrm{~cm}^{-1}$ to $400 \mathrm{~cm}^{-1}$ wave number range for the specimens with different initial MC levels and heat-treated temperatures. The FTIR bands of wood are shown in Table 2. In Figure 1, the initial MC ranged from $5 \%$ to $30 \%$, and the heat treatment temperature was $200^{\circ} \mathrm{C}$. An absorbance peak was detected at $3448 \mathrm{~cm}^{-1}$ corresponding to the $\mathrm{OH}$ hydrophilic group stretching vibration. The peak at $2945 \mathrm{~cm}^{-1}$ was the stretching vibration wave peak that corresponded to $\mathrm{CH}_{3}-\mathrm{CH}_{2-}$. It is also the characteristic wave peak that identifies cellulose. It can be 


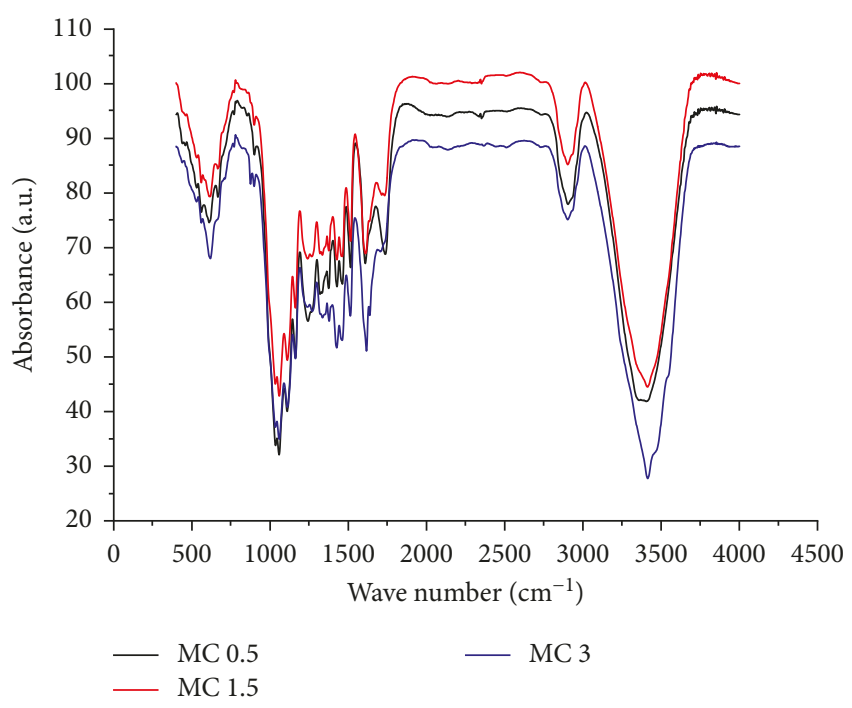

FIgURE 1: The FTIR spectra of specimens with various initial MC levels and heat treated at $200^{\circ} \mathrm{C}$ : MC $0.5, \mathrm{MC} 1.5$, and MC 3 were $5 \%, 15 \%$, and $30 \% \mathrm{MC}$, respectively.

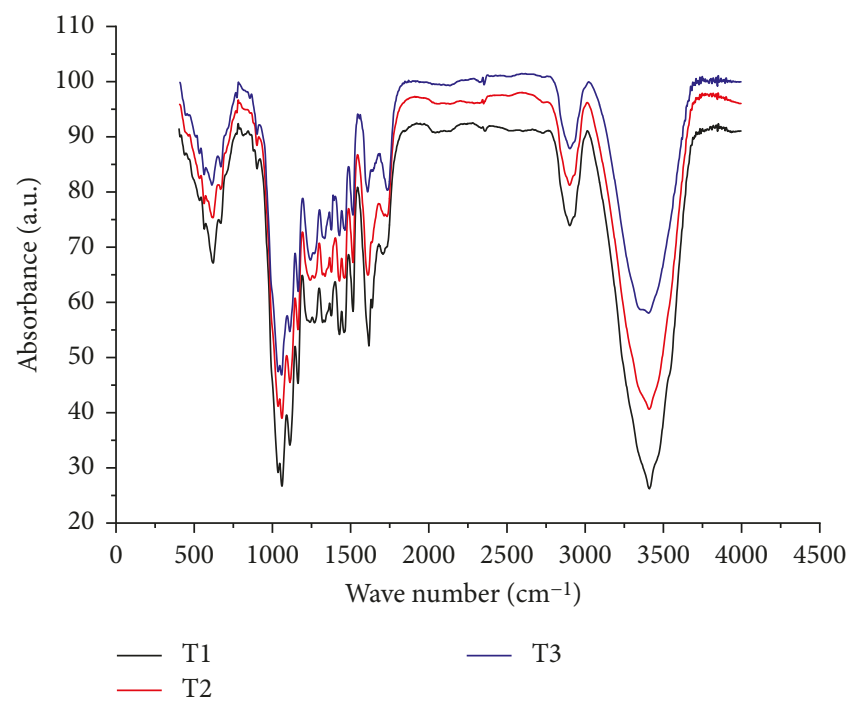

FIgURE 2: The FTIR spectra of specimens that had initial 30\% MC and were heat treated at various temperatures: (T1) $220^{\circ} \mathrm{C},(\mathrm{T} 2)$ $200^{\circ} \mathrm{C}$, and $(\mathrm{T} 3) 180^{\circ} \mathrm{C}$.

seen from spectra that cellulose had lower absorption of infrared light in specimens that had a higher initial MC, which indicated that cellulose degradation occurred. The degradation was much larger when the initial MC was higher. The vibration wave peak at $1751 \mathrm{~cm}^{-1}$ corresponds to carbonyl $\mathrm{C}=\mathrm{O}$, and it is also the characteristic wave peak for hemicellulose [19]. It was obvious that the degradation of hemicellulose was higher in specimens that had a higher initial MC, which demonstrated in another observation of the spectra that the absorption peak at $1076 \mathrm{~cm}^{-1}$ was the stretching vibration absorption wave peak that corresponded to C-O. The absorption peak was lower in specimens that had a higher initial MC, indicating that the
TABLE 2: The FTIR bands of wood.

\begin{tabular}{|c|c|}
\hline $\begin{array}{l}\text { Wave number } \\
\left(\mathrm{cm}^{-1}\right)\end{array}$ & Functional groups \\
\hline 3448 & $\mathrm{OH}$ \\
\hline 2945 & $\mathrm{CH}_{3}-\mathrm{CH}_{2^{-}}$(cellulose) \\
\hline 1751 & $\mathrm{C}=\mathrm{O}$ (hemicellulose) \\
\hline 1592 & A benzene ring skeleton (lignin) \\
\hline 1508 & Aromatic ring skeleton retractable vibration \\
\hline 1425 & $\begin{array}{l}\mathrm{C}-\mathrm{H} \text { plane deformation (aromatic ring } \\
\text { skeleton) }\end{array}$ \\
\hline 1373 & $\begin{array}{c}\text { Condensation of S- and G-type lignin } \\
\text { structures }\end{array}$ \\
\hline 1217 & $\mathrm{C}=\mathrm{O}$ stretching vibration (G-type lignin) \\
\hline 1155 & $\mathrm{C}=\mathrm{O}$ stretching vibration (S-type lignin) \\
\hline 1018 & Aryl C-H plane deformation (G-> S-) \\
\hline 831 & $\begin{array}{l}\text { The deformation out of the plane (S-type } \\
\text { lignin) }\end{array}$ \\
\hline
\end{tabular}

degradation of hemicellulose and cellulose was higher in specimens that had a higher initial MC [20]. The vibration at $1592 \mathrm{~cm}^{-1}$ is the characteristic wave for lignin. Lignin was also degraded during the heat treatment, and the degradation was higher in specimens that had a higher initial MC. The wave number at $1201 \mathrm{~cm}^{-1}$ was an in-plane bending vibration absorption wave peak that corresponded to $\mathrm{O}-\mathrm{H}$.

Figure 2 shows the FTIR spectra of specimens that had an initial 30\% MC and were heat treated at various temperatures. It showed that when the wave number was $3448 \mathrm{~cm}^{-1}$, the amounts of the $\mathrm{OH}$ hydrophilic group decreased and the vibration peaks at $2945 \mathrm{~cm}^{-1}$ and $1751 \mathrm{~cm}^{-1}$ weakened, which indicated that the amounts of hydroxyl, hemicellulose, and cellulose reduced considerably with the increase in the heating temperature. The wave number at $1066 \mathrm{~cm}^{-1}$ was an absorption vibration peak that corresponded to C-O, and the wave number at $1201 \mathrm{~cm}^{-1}$ was an in-plane bending vibration absorption wave peak that corresponded to $\mathrm{O}-\mathrm{H}$. The vibration waves at $1201 \mathrm{~cm}^{-1}$ are absorption wave peaks corresponding to the $\mathrm{O}-\mathrm{H}$ in cellulose and hemicellulose [19]. An absorbance peak was detected at 1155 and $1217 \mathrm{~cm}^{-1}$ corresponding to the $\mathrm{C}=\mathrm{O}$ stretching vibration (S-type lignin and G-type lignin) in curves labeled T1, T2, and T3 in Figure 2. As the absorption wave peaks at $1066 \mathrm{~cm}^{-1}$ and $1201 \mathrm{~cm}^{-1}$ were considerably fewer in the heat-treated specimens, it clearly indicated that the degradation of cellulose and hemicellulose had taken place. The vibration at wave number $939 \mathrm{~cm}^{-1}$ is the vibration of a ring, corresponding to sugars with structures similar to dioxane [21], and Figure 2 demonstrates a possible degradation of these sugars in the heat-treated specimens. The vibration peak at $1591 \mathrm{~cm}^{-1}$, which corresponded to a benzene ring skeleton, was the characteristic wave peak for lignin degraded with the increase in the heating temperature.

3.2. Chemical Analysis of Nutrients. The content of the nutrients via chemical methods is summarized in Table 2 . Figure 3 shows the changes in the content of the nutrients in 


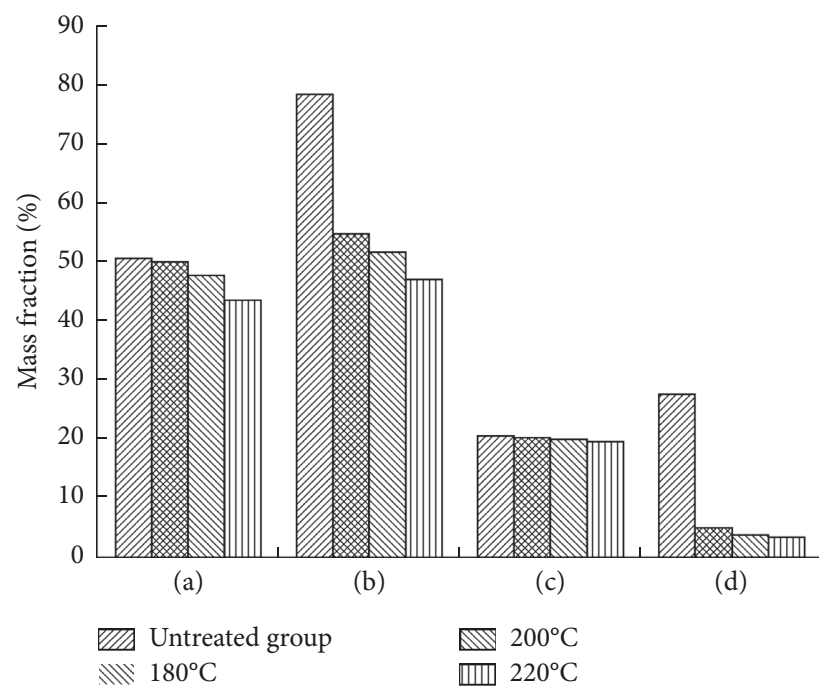

FIgURE 3: The changes in the contents of the nutrients in the specimens that had initial 5\% MC and were treated at various temperatures: (a) cellulose, (b) holocellulose, (c) lignin, and (d) hemicellulose.

TABle 3: Contents of the nutrients in untreated and heat-treated specimens.

Initial MC/heating temperatures

\begin{tabular}{lcccccccccc} 
Nutrient & Untreated & $5 \% / 180^{\circ} \mathrm{C}$ & $15 \% / 180^{\circ} \mathrm{C}$ & $30 \% / 180^{\circ} \mathrm{C}$ & $5 \% / 200^{\circ} \mathrm{C}$ & $15 \% / 200^{\circ} \mathrm{C}$ & $30 \% / 200^{\circ} \mathrm{C}$ & $5 \% / 220^{\circ} \mathrm{C}$ & $15 \% / 220^{\circ} \mathrm{C}$ & $30 \% / 220^{\circ} \mathrm{C}$ \\
\hline Lignin & 0.2071 & 0.2042 & 0.2012 & 0.2005 & 0.201 & 0.1995 & 0.1958 & 0.196 & 0.195 & 0.1951 \\
Cellulose & 0.5059 & 0.4999 & 0.4994 & 0.4819 & 0.479 & 0.4806 & 0.4661 & 0.437 & 0.413 & 0.4164 \\
Holocellulose & 0.7840 & 0.5487 & 0.547 & 0.5274 & 0.517 & 0.5154 & 0.4993 & 0.471 & 0.44 & 0.4424 \\
Hemicellulose & 0.2782 & 0.0488 & 0.0477 & 0.0455 & 0.038 & 0.0349 & 0.0331 & 0.033 & 0.027 & 0.026 \\
\hline
\end{tabular}

the specimens that had an initial 5\% MC and were treated at varying heating temperatures. With the increase in the heating temperature, the amount of cellulose and hemicellulose gradually decreased while the amount of lignin slightly reduced. The results via chemical analysis (Table 3) were in accordance with the results of the FTIR analysis in that the cellulose, hemicellulose, and lignin all degraded as the heating temperature increased. The chemical analysis also showed that the degradation extent for cellulose, hemicellulose, and lignin was greater when the initial MC of the wood was higher. However, it is not apparent as shown in the FTIR analysis due to higher measurement errors.

3.3. Decay Resistance of Heat-Treated Specimens. Table 4 shows the mass loss in the untreated and heat-treated specimens via the decay resistance of white rot fungus for 4 weeks. Figure 4 shows the weight loss trend comparing the untreated specimens with heat-treated specimens via the decay resistance of white rot fungus for 4 weeks. It is obvious that the weight loss reduced with increased heating temperature, and the decay resistance was improved. The weight loss of the heat-treated specimens with initial 30\% MC was lower than the other specimens, and the differences were not quite significant [9]. With the increase in the thermotreatment temperature, the crystallinity of cellulose was decreased. It is possible that the bound water with high temperature was removed from the cellulose (Table 5). The hydrogen bonds and the proper conditions for the crystallization were destroyed. The cellulose crystalline site began to oxidize at high temperature. The color of cellulose changed to tan while the crystallinity obviously decreased. The crystallinity of cellulose drastically decreased when heat treated at $220^{\circ} \mathrm{C}$.

3.4. FTIR Analysis of Heat-Treated and Fungi-Infested Specimens. Figure 5 shows the spectra of the specimens that had an initial $15 \% \mathrm{MC}$, were heat treated at various temperatures, and were then infested with the white rot fungus for 4 weeks. The characteristic wave peak of cellulose at the wave number $2945 \mathrm{~cm}^{-1}$ made a great difference. It was probably that the cellulose hydrolysis occurred. A hydrogen bond can form between the neighboring cellulose molecules, resulting in a Fermi resonance vibration [22]. The absorption vibration wave peak at $3448 \mathrm{~cm}^{-1}$ that corresponded to $-\mathrm{OH}$ was higher as the heating temperature was lower. The primary reason for this was that as cellulose and lignin were degraded by their respective enzymes, the amounts of hydroxyls subsequently increased [23].

Figure 6 shows the FTIR spectra of the specimens that had various initial MC, were heat treated at $220^{\circ} \mathrm{C}$, and were then infested by the white rot fungus for 4 weeks. The vibration wave peak at $3448 \mathrm{~cm}^{-1}$ was higher for specimens with higher initial MC. The characteristic vibration wave peak at $2945 \mathrm{~cm}^{-1}$ for cellulose showed a more obvious 
TABLE 4: Weight loss of untreated and heat-treated specimens after decay resistance tests.

\begin{tabular}{lccc}
\hline $\begin{array}{l}\text { Set no. of } \\
\text { specimens }\end{array}$ & $\begin{array}{c}\text { Initial MC } \\
(\%)\end{array}$ & $\begin{array}{c}\text { Heating } \\
\text { temperatures }\left({ }^{\circ} \mathrm{C}\right)\end{array}$ & $\begin{array}{c}\text { Weight loss } \\
(\%)\end{array}$ \\
\hline 1 & 30 & 220 & 8.69 \\
2 & 15 & 220 & 10.80 \\
3 & 5 & 220 & 10.88 \\
4 & 30 & 200 & 10.40 \\
5 & 15 & 200 & 11.07 \\
6 & 5 & 200 & 11.60 \\
7 & 30 & 180 & 12.16 \\
8 & 15 & 180 & 13.29 \\
9 & 5 & 180 & 13.35 \\
10 & 30 & Untreated & 28.94 \\
11 & 15 & Untreated & 22.23 \\
12 & 5 & Untreated & 21.09 \\
\hline
\end{tabular}

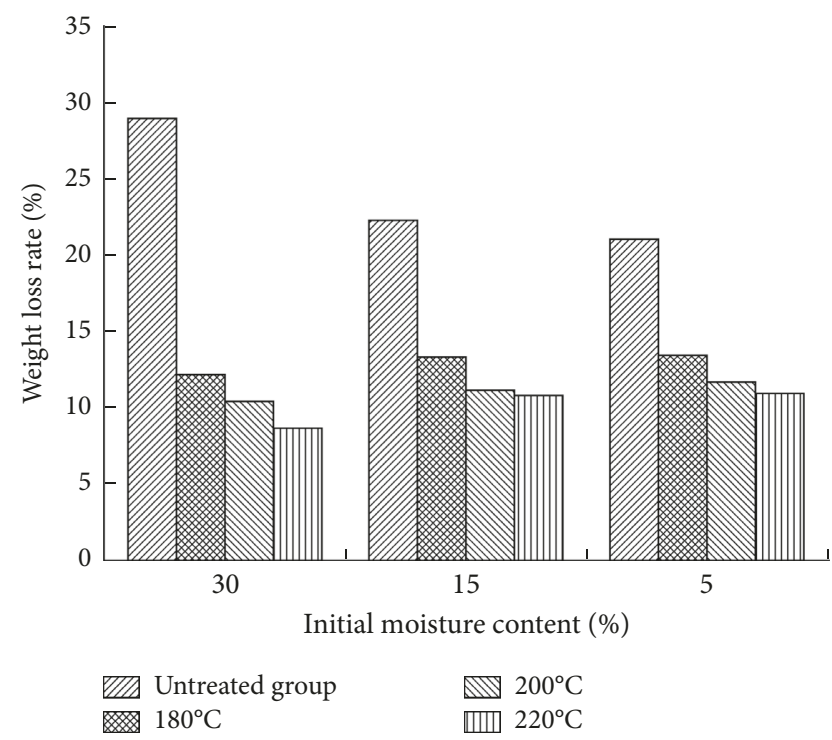

FIGURE 4: Weight losses of untreated and heat-treated specimens with various initial MC levels and infested by the white rot for 4 weeks.

change in the specimens with higher initial MC. Several reasons can explain this phenomenon. First of all, the degradation amounts of hemicellulose were greater in specimens with a higher initial MC than in specimens with an initial MC below 15\%. Also, the white rot fungus firstly decomposed the cellulose and then hydrolyzed cellulose. The main reason was that because of the T1 specimens with a higher initial moisture content than the T2 and T3 specimens, the hydrolysis in the T1 specimens was faster, which was beneficial to make the cellulose degradation increase. However, the degradation was totally incomplete. The relative amounts of the $\mathrm{C}-\mathrm{O}$ bond at $1066 \mathrm{~cm}^{-1}$ of the curves $\mathrm{T} 1, \mathrm{~T} 2$, and $\mathrm{T} 3$ slightly changed, which was also evident that the cellulose degradation in these specimens was incomplete (i.e., the cellulose was not completely utilized by
TABLE 5: Crystallinity of untreated and heat-treated specimens.

\begin{tabular}{lccc}
\hline Type & $\begin{array}{c}\text { Initial MC } \\
(\%)\end{array}$ & $\begin{array}{c}\text { Heating temperatures } \\
\left({ }^{\circ} \mathrm{C}\right)\end{array}$ & $\begin{array}{c}\text { Crystallinity } \\
(\%)\end{array}$ \\
\hline 1 & 15 & 0 & 89.4 \\
2 & 15 & 180 & 82.7 \\
3 & 15 & 200 & 73.6 \\
4 & 15 & 220 & 68.3 \\
\hline
\end{tabular}

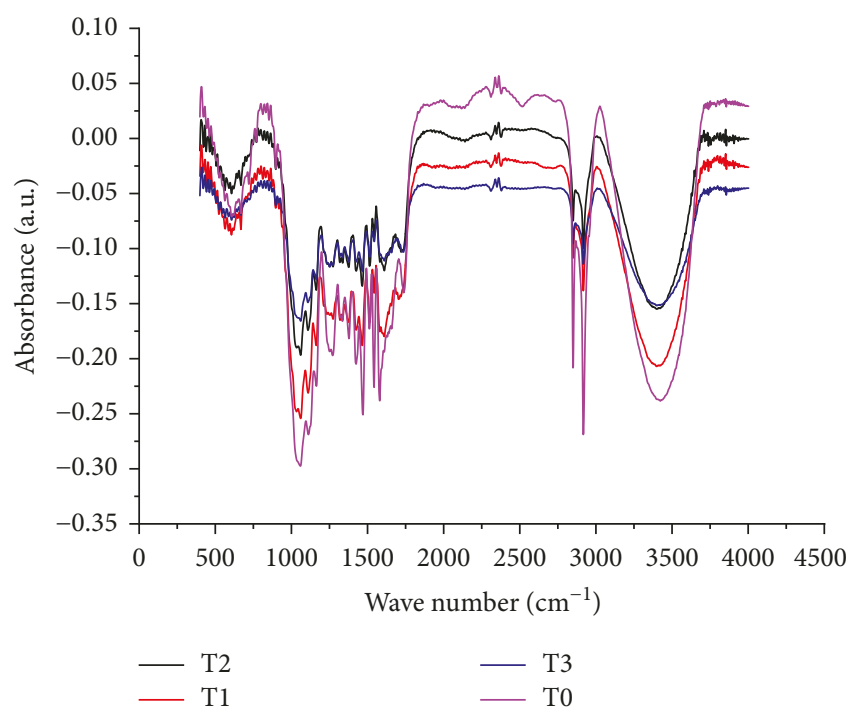

FIgURE 5: The FTIR spectra of the specimens with initial 15\% MC, at various temperatures, and then infested by the white rot for 4 weeks: (T0) untreated, (T1) $220^{\circ} \mathrm{C},(\mathrm{T} 2) 200^{\circ} \mathrm{C}$, and (T3) $180^{\circ} \mathrm{C}$.

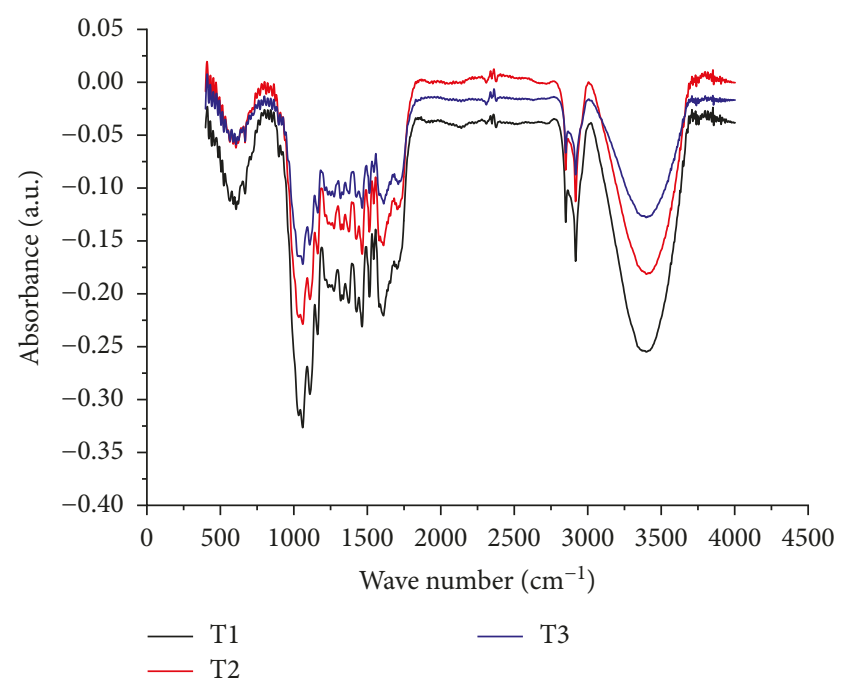

FIGURE 6: The FTIR spectra of specimens with various initial MC levels, heat treated at $220^{\circ} \mathrm{C}$, and infested by the white rot for 4 weeks: (T1) 30\% MC, (T2) 15\% MC, and (T3) 5\% MC.

the fungus), and both the amount of the $\mathrm{OH}$ bond and the degree of hygroscopy increased in the curve T1.

Figure 7 shows the FTIR spectra of specimens with an initial 5\% MC, which were either untreated or heat treated at 


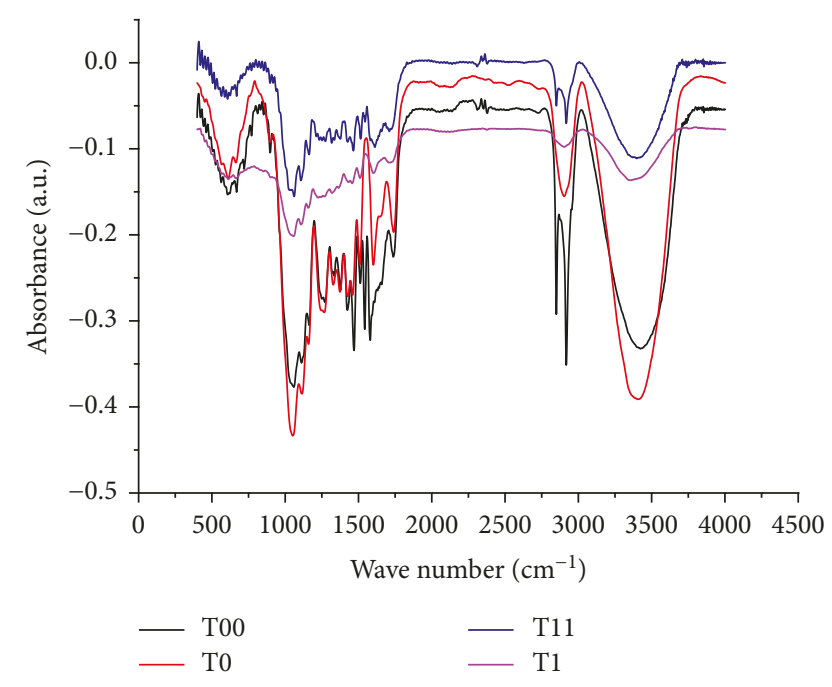

FIgURE 7: The FTIR spectra of specimens with the same initial 5\% MC and various experimental conditions: (T1) heat treated at $220^{\circ} \mathrm{C}$ and fungal-infested, (T11) heat treated at $220^{\circ} \mathrm{C}$ and no fungal infestation, (T0) no heat treatment and no fungal infestation, and (T00) no heat treatment and fungal infested.

$220^{\circ} \mathrm{C}$, with and without fungal infestation for 4 weeks. The vibration wave peak at $2945 \mathrm{~cm}^{-1}$ was noticeably less for the heat-treated and fungal-infested specimens than that for the untreated specimens. The absorption vibration wave peak at $3448 \mathrm{~cm}^{-1}$ for hydroxyl became lower. It was possible due to the decomposition of hemicellulose, sugars, and cellulose, as well as the subsequent consumption of the resultant monosaccharides and lignin by the white rot fungus. The amount of hemicellulose that corresponded to $1751 \mathrm{~cm}^{-1}$ reduced considerably for the control specimens (without heat treatment and fungal infestation). The absorption vibration wave peak at $1591 \mathrm{~cm}^{-1}$ was considerably lower for the heat-treated and fungal-infested specimens (Figure 7, T1), whereas it shifted for the heat-treated and nonfungalinfested specimens (Figure 7, T11), indicating lignin degradation, and the amount of degradation was greater in the heat-treated specimens.

In summary, with the increase in the heating temperature, the cellulose, hemicellulose, and lignin all degraded. In addition, the initial moisture content of the wood had a large influence on the amount of degradation. The factors of the nutrient degradation, the reduction of moisture content, the acetylation reaction, and the esterification reaction due to the heat treatment changed. The growth of white rot fungus was inhibited via changing the living environment and the supply of nutrients needed by white rot fungus, and hence, the decay resistance of the wood was improved.

\section{Conclusions}

(1) The FTIR analysis showed that the cellulose, hemicellulose, and lignin in the wood underwent various degrees of degradation, and the sugars also degraded with the increase in the heating temperature. The available nutrients to the white rot fungus decreased.
(2) The degradation of nutrients via the heat treatment was higher in specimens with a higher initial moisture content.

(3) With the increase in the heating temperature, the cellulose, hemicellulose, and lignin degraded. It also showed relationships between the initial moisture content of the wood and the amount of degradation of the nutrients. It was not as apparent via the FTIR analysis.

(4) Decay resistance tests of untreated and heat-treated specimens showed that the average weight loss of the heat-treated specimens after fungal infestation was $10.8 \%$, in contrast to $22.23 \%$ for the untreated specimens. Decay resistance improved as the heating temperature increased. The vibration wave peaks at $2945 \mathrm{~cm}^{-1}, 1751 \mathrm{~cm}^{-1}$, and $1591 \mathrm{~cm}^{-1}$ noticeably split less, which indicated that the hydrolysis action of cellulose had reduced, which meant less susceptibility to decay.

\section{Conflicts of Interest}

The authors declare that they have no conflicts of interest.

\section{Authors' Contributions}

Yinan Hao and Yanfei Pan contributed equally to this work.

\section{Acknowledgments}

The authors gratefully acknowledge the financial support from the National Majority R\&D Program of China (2016YFD0600701), the Innovation Team of Desert Shrub Fibrosis and Energy Utilization Technology of the Inner Mongolia Autonomous Region, Key Laboratory of BioBased Material Science \& Technology (Northeast Forestry University), Ministry of Education (SWZCL2016-10), the Inner Mongolia Autonomous Region grassland person, the Talent Foundation of the Inner Mongolia, the Major Guidance Foundation of the Inner Mongolia Autonomous Region (20131506, 20140609, and 201501041), the Achievements Transformation Foundation of the Inner Mongolia Agricultural University (CGZH2014009), and The Start-up Project of Inner Mongolia Agricultural University Highlevel Talents Introduction Scientific Research (NDYB2016-24).

\section{References}

[1] O. Skyba, P. Niemz, and F. W. Schwarze, "Degradation of thermo-hygro-mechanically (THM)-densified wood by softrot fungi," Holzforschung, vol. 62, no. 3, pp. 277-283, 2008.

[2] J. B. Paes, V. M. Morais, and C. R. Lima, "Natural resistance of nine woods of Brasilian semi-arid region to wood-destroying fungi under laboratory conditions," Revista Arvore, vol. 28, no. 2, pp. 275-282, 2004.

[3] Y. D. Zhou, X. M. Jiang, and J. L. Liu, "Development and application of heat-treatment techniques for lumber," China Wood Industry, vol. 20, no. 5, pp. 1-3, 2006.

[4] K. H. Lee, S. G. Wi, A. P. Singh, and Y. S. Kim, "Micro morphological characteristics of decayed wood and laccase 
produced by the brown-rot fungus Coniophora puteana," Journal of Wood Science, vol. 50, no. 3, pp. 281-284, 2004.

[5] F. W. M. R. Schwarze, "Wood decay under the microscope," Fungal Biology Reviews, vol. 21, no. 4, pp. 133-170, 2007.

[6] L. Murmanis, T. L. Highley, and J. G. Palmer, "The action of isolated brown-rot cell-free culture filtrate, $\mathrm{H}_{2} \mathrm{O}_{2}-\mathrm{Fe}^{++}$, and the combination of both on wood," Wood Science and Technology, vol. 22, no. 1, pp. 59-66, 1988.

[7] L. Homolka, F. Nerud, O. Kofroňová, E. Novotná, and V. Machurová, "Degradation of wood by the basidiomycete coriolopsis occidentalis," Folia Microbiologica, vol. 39, no. 1, pp. 37-43, 1994.

[8] C. H. Cho, K. H. Lee, J. S. Kim, and Y. S. Kim, "Micromorphological characteristics of bamboo (Phyllostachys pubescens) fibers degraded by a brown rot fungus (Gloeophyllum trabeum)," Journal of Wood Science, vol. 54, no. 3, pp. 61-265, 2008.

[9] B. M. Esteves and H. M. Pereira, "Wood modification by heat treatment: a review," BioResources, vol. 4, no. 1, pp. 370-404, 2009.

[10] P. Huseyin and Y. Mesut, "Resistance of mechanically densified and thermally post-treated pine sapwood to wood decay fungi," Journal of Wood Science, vol. 63, no. 5, pp. 514-522, 2017.

[11] A. M. Manninen, P. Pasanen, and J. K. Holopainen, "Comparing the VOC emissions between air-dried and heat-treated Scots pine wood," Atmospheric Environment, vol. 36, no. 11, pp. 1763-1768, 2002.

[12] J. Y. Kim, H. Hwang, S. Oh, Y. S. Kim, U. J. Kim, and J. W. Choi, "Investigation of structural modification and thermal characteristics of lignin after heat treatment," International Journal of Biological Macromolecules, vol. 66, no. 5, pp. 57-65, 2014.

[13] L. Nunes, T. Nobre, and A. Rapp, Thermally Modified Wood in Choice Tests with Subterranean Termites, COST E37, Reinbeck, IA, USA, 2004.

[14] Y. M. Wang, S. L. Ma, and L. Q. Feng, “The influence of oil heat treatment on wood decay resistance by Fourier infrared spectrum analysis," Spectroscopy and Spectral Analysis, vol. 34, no. 3, pp. 660-663, 2014.

[15] GB/T 13942.1, Durability of Wood-Part 1: Method for Laboratory Test of Natural Decay Resistance, Standardization Administration of China, Beijing, China, 2009.

[16] GB/T 2677.10, Fibrous Raw Material-Determination of Holocellulose, Standardization Administration of China, Beijing, China, 1995.

[17] GB/T 744, Pulps-Determination of Alkali Resistance, Standardization Administration of China, Beijing, China, 2004.

[18] GB/T 2677.8, Fibrous Raw Material-Determination of AcidInsoluble Lignin, Standardization Administration of China, Beijing, China, 1994.

[19] J. Li, Wood Spectroscope, Science Press, Beijing, China, 2003.

[20] M. Hakkou, M. Petrissans, A. Zoulalian, and P. Gérardin, "Investigation of wood wettability changes during heat treatment on the basis of chemical analysis," Polymer Degradation and Stability, vol. 89, no. 1, pp. 1-5, 2005.

[21] W. P. He, Concise Identification of Infrared Spectroscopy Method, Guangxi Normal University Press, Guilin, China, 1992.

[22] X. X. He and D. Q. Sun, Practical Infrared Spectroscopy, Petroleum Industry Press, Beijing, China, 1982.

[23] D. K. Shen, S. Gu, and A. V. Bridgwater, "The thermal performance of the polysaccharides extracted from hardwood: cellulose and hemicellulose," Carbohydrate Polymers, vol. 82, no. 1, pp. 39-45, 2010. 


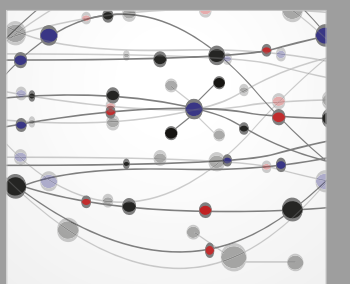

The Scientific World Journal
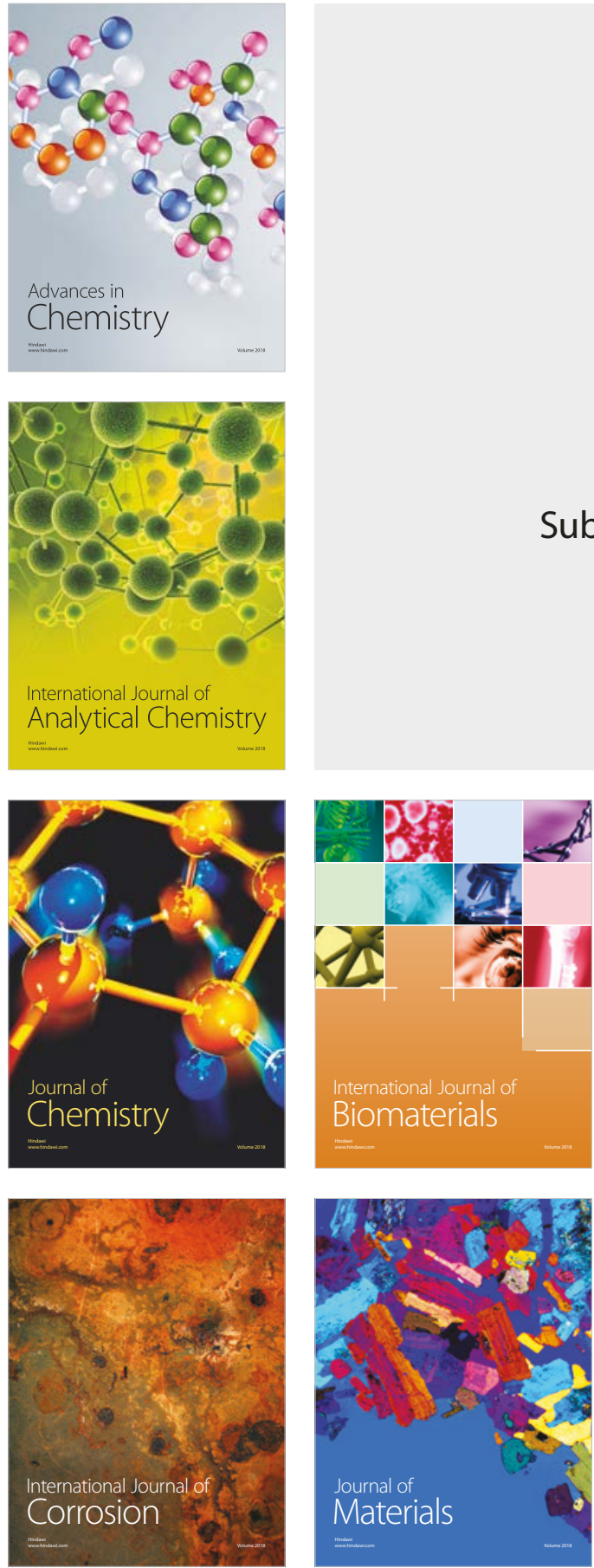

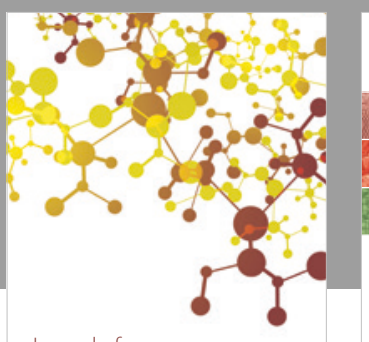

Journal of

Applied Chemistry
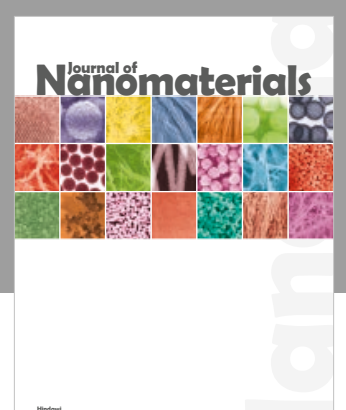

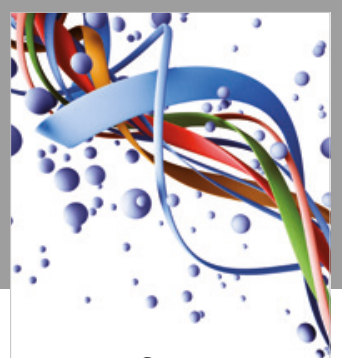

Scientifica

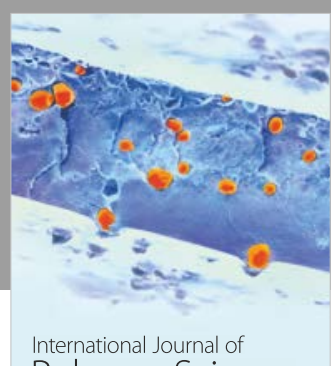

Polymer Science

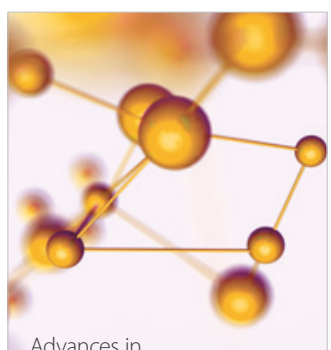

Physical Chemistry
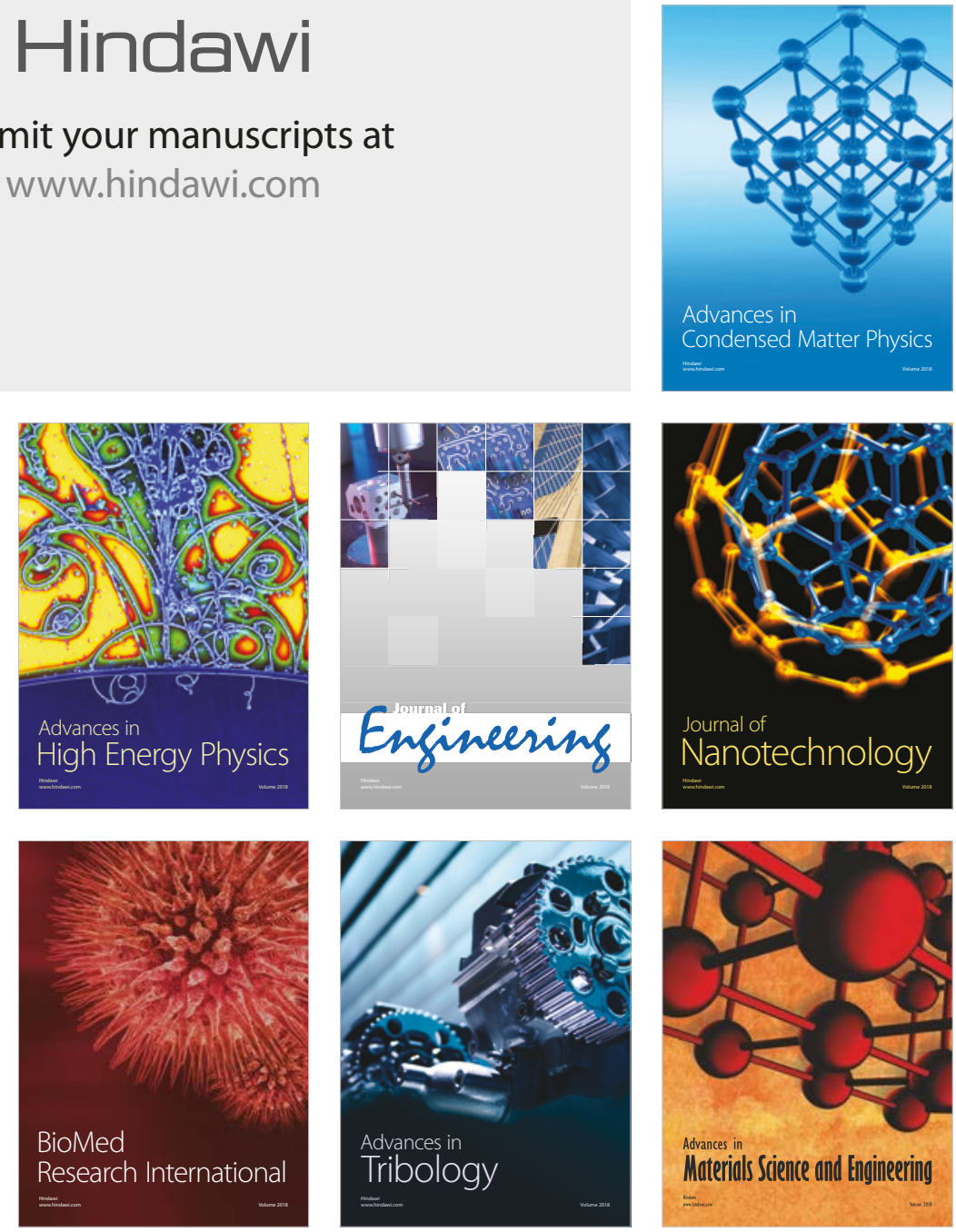